\title{
Dukungan keluarga pada ibu bekerja dalam memberikan ASI eksklusif di negara berkembang: Scoping review
}

\author{
Gana Rendra Winarti ${ }^{1 *}$, Cesa Septiana Pratiwi ${ }^{2}$ \\ 1,2 Universitas 'Aisyiyah Yogyakarta
}

\section{INFORMASI ARTIKEL:}

\begin{tabular}{l}
\hline Riwayat Artikel: \\
Tanggal diterima, 4 Oktober 2021 \\
Tanggal direvisi, 13 November 2021 \\
Tanggal dipublikasi, 5 Desember 2021 \\
\hline Kata kunci: \\
Ibu Bekerja \\
Dukungan Keluarga atau Pengalaman \\
Menyusui \\
Negara Berkembang
\end{tabular}

$10.32536 / j$ jki.v5i2.200

Key word: Working Mothers Family support OR Experience, Breasfeeding OR Lactation Developing country

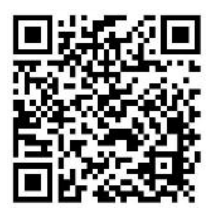

\begin{abstract}
ABSTRAK
Latar Belakang: Makanan terbaik untuk bayi adalah ASI. Pekerjaan ibu turut memberikan peran pada turunnya angka pemberian ASI eksklusif. Memberikan ASI atau menyusui merupakan perilaku yang dapat diajarkan oleh keluarga kepada ibu dengan memberikan dukungan keluarga. Tujuan penelitian: mereview literature yang membahas tentang dukungan keluarga terhadap ibu bekerja dalam memberikan ASI eksklusif di negara berkembang. Metode: Penyusunan scoping review menggunakan framework dari Arksey dan O'Malley. Hasil: Berdasarkan 7 artikel terseleksi 4 dengan desain kuantitatif, 2 desain kualitatif dan 1 desain mixed methode. Hasil penelitian mendapatkan tiga tema yaitu faktor yang mempengaruhi keberhasilan pemberian ASI Eksklusif, bentuk dukungan dan hambatan yang dialami dalam pemberian ASI Eksklusif. Simpulan: Dukungan keluarga termasuk dukungan suami adalah salah satu faktor yang terkait dengan pemberian ASI secara EKsklusif. Ditemukan bahwa kurangnya dukungan dari tempat kerja menjadi penghambat dalam pemberian ASI secara Eksklusif.
\end{abstract}

Background: The best food for babies is breast milk. A mother's occupation plays a role in decreasing the rate of exclusive breastfeeding. Breastfeeding is a behavior that can be taught by families to mothers by providing family support. Objectives: To review the literature that discusses family support for working mothers in providing exclusive breastfeeding in developing countries. Methods: Preparation of a scoping review using the framework of Arksey and O'Malley. Results: Based on 7 selected articles, 4 with quantitative designs, 2 qualitative designs, and 1 mixed-method design. The results of the study found three themes including factors that influence the success of exclusive breastfeeding, forms of support, and barriers experienced in exclusive breastfeeding. Conclusion: Family support including the husband's support is one of the factors associated with exclusive breastfeeding. It is also found that the lack of workplace support is a barrier to exclusive breastfeeding.

\section{Pendahuluan}

Menyusui yaitu cara yang efektif demi memastikan kelangsungan hidup dan kesehatan anak. World Health Organization (WHO) menyarankan supaya ibu mulai menyusui bayinya segera 1 jam setelah melahirkan. Sangatlah penting memberikan ASI eksklusif terutama 6 bulan pertama demi tercapainya kehidupan pertumbuhan yang optimal. Makanan yang cukup, makanan dengan gizi yang seimbang serta aman dan bayi terus menyusu adalah salah satu cara untuk memenuhi nutrisi dan tumbuh kembang bayi (WHO, 2018).

\footnotetext{
* Korespondensi penulis.

Alamat E-mail: ganarendra1311@gmail.com
}

ASI merupakan air susu yang banyak mengandung nutrisi optimal, yang baik kualitas dan kuantitas untuk bayi. Salah satu cara memberikan makanan untuk bayi yaitu denga ASI. Kandungan ASI yang banyak akan kandungan gizi dan salah satu cairan yang dibutuhkan oleh bayi (Sulistiyowati and Siswantara, 2014). Makanan paling baik untuk bayi adalah ASI. karena di dalam ASI banyak terkandung gizi dalam jumlah dan komposisi yang seimbang dan ideal yang sangat diperlukan oleh tubuh bayi untuk proses pertumbuh dan perkembangannya (Sartono and Utaminingrum, 2012)

Ibu bekerja adalah ibu yang melakukan kegiatan di luar rumah seperti bekerja di pabrik sebagai buruh dan di kantor, menjalankan bisnis atau usaha pribadi untuk menambah pemasukan tambahan serta banyak menyita waktu di luar 
rumah (Sulistiyowati and Siswantara, 2014). Pekerjaan ibu turut memberikan peran pada turunnya angka pemberian ASI eksklusif. Pada praktiknya sulit untuk mendapatkan ASI eksklusif terkhusus bagi ibu yang bekerja diluar rumah. Kembalinya bekerja lebih awal, cuti melahirkan yang singkat, tidak waktu istirahat untuk menyusui atau pompa ASI dan kurang alat untuk memerah ASI menjadi pemicu ibu tidak bisa memberikan ASI secara eksklusif (Ratnasari et al. 2017).

\section{Metode penelitian}

Scoping review adalah upaya untuk mengidentifikasi literatur atau sumber yang tersedia dengan berbagai macam metode penelitian yang terkait dengan topik penelitian (Arksey and O'Malley, 2005). Dalam menyusun scoping review ada beberapa tahapan yang harus peneliti lakukan. Tahapan ini mengacu pada Arksey O'Malley (2005). Adapun tahapannya yaitu: (1) mengidentifikasi pertanyaan penelitian dan disesuaikan dengan tujuan penelitian, (2) mengidentifikasi sumber literatur yang relevan melalui berbagai sumber, (3) seleksi literatur yang telah di dapat menyesuaikan dengan topik penelitian, (4) melakukan pemetaan dan mengumpulkan literatur yang digunakan, (5) menyusun dan melaporkan hasil analisis literatur yang telah dipilih dan (6) konsultasi kepada pihak kompeten.

\section{Langah 1: Identifikasi pertanyaan scoping review}

Langkah awal scoping review dengan mengidentifikasi pertanyaan penelitian disesuaikan dengan tujuan yang diteliti. Pada tahap pertanyaan ini peneliti melakukan identifikasi pertanyaan yang bertujuan sebagai acuan dalam mencari artikel. Pentingnya mempertimbangkan aspek dari pertanyaan penelitian misalnya populasi intervensi dan hasil agar memperoleh penelitian yang berkualitas (Arksey and O'Malley, 2005). Dalam scoping review ini menggunakan format pertanyaan populations, exposure, outcome, dan setting (PEOS). Dari hal yang telah dijabarkan, pertanyaan dalam penelitian ini yaitu "bagaimana dukungan keluarga yang diterima ibu bekerja dalam memberikan ASI eksklusif di negara berkembang?"

Tabel 1. Framework PEOS

\begin{tabular}{ll}
\hline Population & Ibu yang bekerja dan menyusui \\
\hline Exposure & Dukungan keluarga \\
\hline Outcome & ASI Eksklusif \\
\hline Setting & Negara berkembang \\
\hline
\end{tabular}

\section{Langkah 2: Identifikasi Sumber Literatur Yang Relevan}

Dalam melakukan review peneliti melakukan identifikasi artikel yang relevan dengan menetapkan 2 kriteria yaitu inklusi dan eksklusi.

Table $\mathbf{2}$ Kriteria Inklusi dan Eksklusi

\begin{tabular}{|c|c|}
\hline Kriteria Inklusi & Kriteria Eksklusi \\
\hline $\begin{array}{l}\text { a. Diterbitkan dari tahun } 2010 \\
\text { sampai dengan } 2020 \\
\text { b. Diterbitkan dalam Bahasa } \\
\text { Inggris atau Bahasa } \\
\text { Indonesia } \\
\text { c. Artikel yang membahas } \\
\text { tentang siapa pemberi } \\
\text { dukungan utama ibu bekerja } \\
\text { dalam memberikan ASI } \\
\text { Esklusif di Negara } \\
\text { Berkembang yang membahas } \\
\text { d. Artikel yang dukungan } \\
\text { tentang bentuk dibu } \\
\text { keluarga yang terima ibu } \\
\text { bekerja dalam memberikan } \\
\text { ASI Eksklusif di Negara } \\
\text { Berkembang yang membahas } \\
\text { e. Artikel yang yakerja dalam } \\
\text { tentang faktor-faktor yang } \\
\text { faktor yang mempengaruhi } \\
\text { dukungan yang diterima } \\
\text { oleh ibu pekerja } \\
\text { memberikan ASI Eksklusif di } \\
\text { Negara Berkembang }\end{array}$ & $\begin{array}{l}\text { a. Dokumen laporan / draf } \\
\text { kebijakan / pedoman dari } \\
\text { WHO / organsasi formal } \\
\text { tertentu } \\
\text { b. Artikel yang membahas } \\
\text { tentang prefalensi ASI } \\
\text { Eksklusif di Negara } \\
\text { Berkembang } \\
\text { c. Artikel yang membahas } \\
\text { tentang cakupan ASI } \\
\text { Eksklusif di Negara } \\
\text { Berkembang } \\
\text { d. Artikel yang membahas } \\
\text { tentang angka keberhasilan } \\
\text { ASI Eksklusif di Negara } \\
\text { Berkembang }\end{array}$ \\
\hline
\end{tabular}

\section{Langkah 3: Seleksi literature}

Sumber literatur yang diperoleh melalui pencarian dengan menggunakan beberapa search engine. Search engine yang dimaksud terdiri dari PubMed, Science Direct, dan Wiley (Widiasih et al. 2020). Pada penulisan scoping review ini, peneliti mendokumentasikan pencarian literatur mengikuti pedoman Preferred Reporting Items for Systematic reviews and Meta-Analyses (PRISMA). Kemudian data disaring sesuai dengan kriteria yang peneliti tentukan. Adapun tahap-tahan penyaringan data disajikan pada gambar 1.

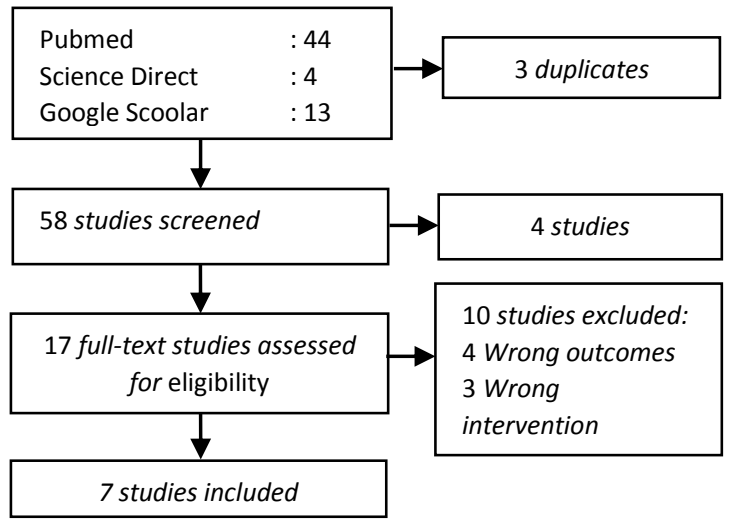

Gambar 1. Prisma Flowchart 
Setelah melakukan pemilihan studi, untuk mengetahui kualitas artikel yang telah dipilih, maka dilakukan critical appraisal. Critical Appraisal dalam Scoping review ini menggunakan The Joanna Briggs Institute (JBI) Critical Appraisal Tools. JBI adalah sebuah organisasi penelitian dan pengembangan yang berbasis Internasional, JBI mengkhususkan pada promosi dan mendukung pelayanan kesehatan yang berdasarkan bukti. Critical appraisal dianggap sebagai proses untuk menilai artikel penelitian secara cermat dan

\section{Langkah 4: Data Charting}

Berdasarkan 7 artikel yang telah di pilih, langkah selanjutnya dilakukan charting data untuk menggolongkan beerapa artikel seperti: judul, sistematis sebagai penentu keandalan, validitas sama dan penerapan dalam praktik klinis.

Pada tahap critical appraisal terdapat 7 artikel yang sesuai dengan topik dan kriteria inklusi yang sudah ditetapkan oleh penulis, studi desain yang digunakan meliputi kualitatif dan cross-sectional. Masing-masing metode penelitian memiliki checklist critical appraisal yang berbeda. Untuk menilai 7 artikel yang masuk pada tahap critical appraisal penulis menggunakan skala grade A, B, dan $C$ untuk membedakan kategori artikel yang masuk dalam kategori baik (Grade A), cukup baik (Grade B), dan kurang baik (Grade C)

desain penelitian, dan hasil temuan dari penelitian tersebut.

Table 3. Data Charting

\begin{tabular}{|c|c|c|c|c|c|c|}
\hline No & Judul/penulis/tahun & Negara & Tujuan & $\begin{array}{c}\text { Jenis } \\
\text { peneliian }\end{array}$ & Metode & Hasil \\
\hline 1 & $\begin{array}{ll}\text { (Swastika, } & \text { Rao } \\
\text { Arathi, } & \text { and } \\
\text { Guddattu } & \\
\text { 2018)/(Factors } & \\
\text { affecting exclusive } \\
\text { breastfeeding (EBF) } \\
\text { among working } \\
\text { mothers) }\end{array}$ & India & $\begin{array}{l}\text { Tujuan dari } \\
\text { penelitian ini } \\
\text { yaitu untuk } \\
\text { mempengaruhi } \\
\text { faktor apa saja } \\
\text { yang berpegrur } \\
\text { ibu bekerja } \\
\text { dalam menyuui } \\
\text { secara Eksklusif }\end{array}$ & $\begin{array}{l}\text { cross- } \\
\text { sectiona }\end{array}$ & 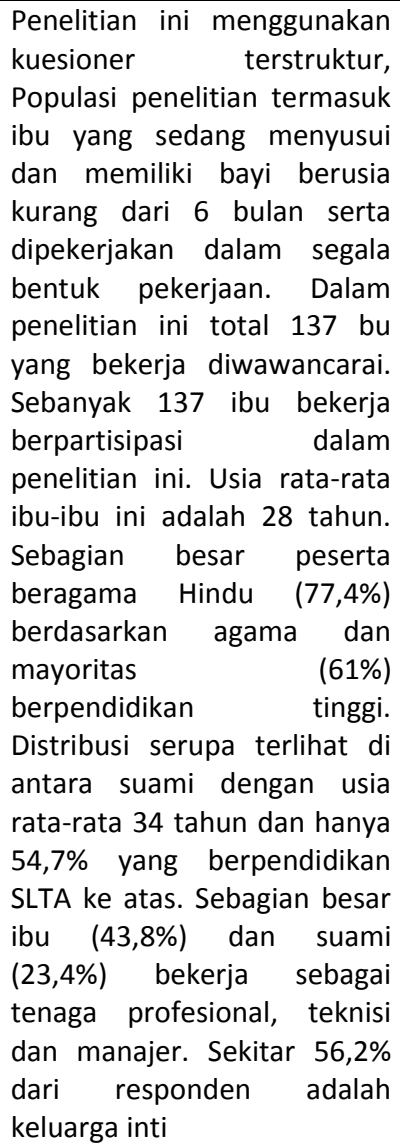 & 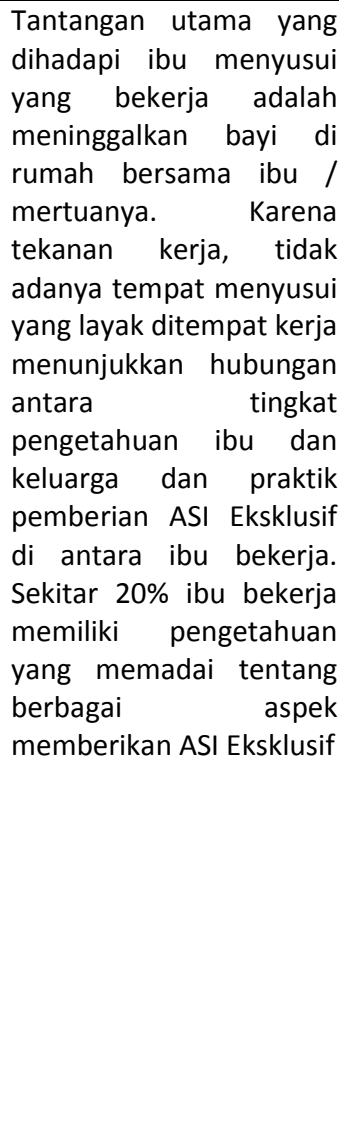 \\
\hline
\end{tabular}




\begin{tabular}{|c|c|c|c|c|c|c|}
\hline 2 & $\begin{array}{l}\text { (Februhartanty et } \\
\text { al. 2012)/(Profiles } \\
\text { of eight working } \\
\text { mothers who } \\
\text { practiced exclusive } \\
\text { breastfeeding) }\end{array}$ & $\begin{array}{l}\text { Indon } \\
\text { esia }\end{array}$ & $\begin{array}{l}\text { Tujuan dari } \\
\text { penelitian ini } \\
\text { yaitu untuk } \\
\text { menggali } \\
\text { karakteristik ibu } \\
\text { bekerja yang } \\
\text { mampu } \\
\text { mempraktikkan } \\
\text { ASI eksklusif }\end{array}$ & $\begin{array}{l}\text { Studi } \\
\text { kuantita } \\
\text { tif dan } \\
\text { Studi } \\
\text { kualitati } \\
\text { f }\end{array}$ & 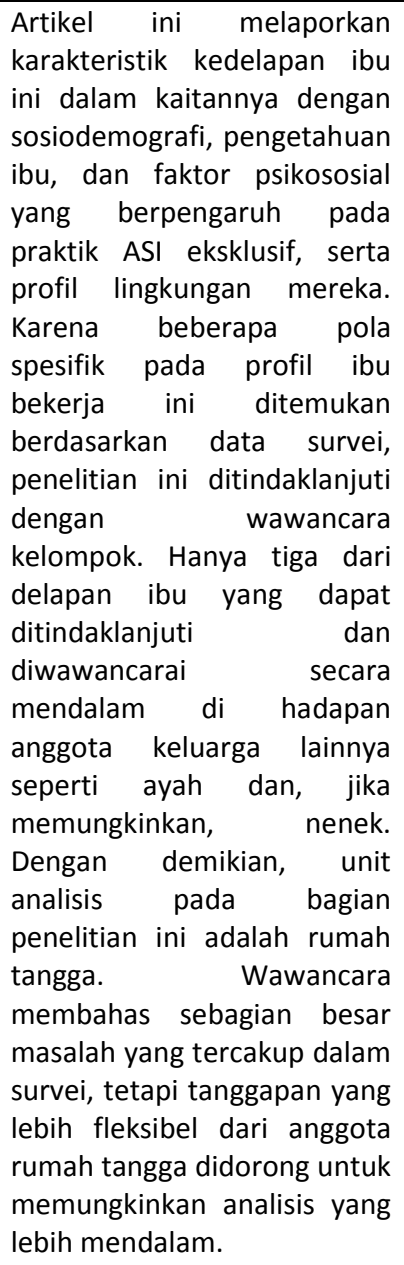 & 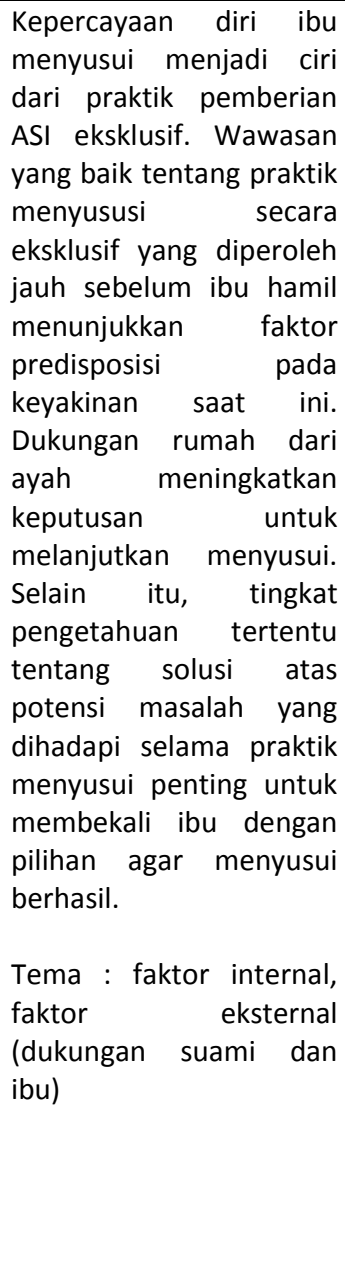 \\
\hline 3 & $\begin{array}{l}\text { (Hidayah Putri, } \\
\text { Masrul, and } \\
\text { Evareny 2018)/(The } \\
\text { Relationship } \\
\text { Between The Level } \\
\text { of Maternal } \\
\text { Knowledge, } \\
\text { Maternal } \\
\text { Employment Status } \\
\text { and Family Support } \\
\text { With Exclusive } \\
\text { Breastfeeding) }\end{array}$ & $\begin{array}{l}\text { Indon } \\
\text { esia }\end{array}$ & $\begin{array}{l}\text { Penelitian ini } \\
\text { bertujuan untuk } \\
\text { mengetahui } \\
\text { hubungan } \\
\text { tingkat } \\
\text { pengetahuan } \\
\text { ibu, status } \\
\text { pekerjaan ibu } \\
\text { serta peran } \\
\text { serta dukungan } \\
\text { keluarga } \\
\text { dengan } \\
\text { pemberian ASI } \\
\text { Eksklusif }\end{array}$ & $\begin{array}{l}\text { Cross } \\
\text { sectiona } \\
\text { I }\end{array}$ & $\begin{array}{l}\text { Riset analitik dengan desain } \\
\text { cross sectional, sampel dalam } \\
\text { penelitian ini ibu yang } \\
\text { memiliki balita usia kurang } \\
\text { dari } 6 \text { sampai } 12 \text { bulan } \\
\text { sebanyak } 56 \text { orang. Ibu yang } \\
\text { ditetapkan sebagai } \\
\text { responden diwawancarai } \\
\text { langsung menggunakan } \\
\text { kuesioner. Analisis data } \\
\text { dilakukan secara univariat } \\
\text { dan bivariat menggunakan } \\
\text { analisis pahat. }\end{array}$ & 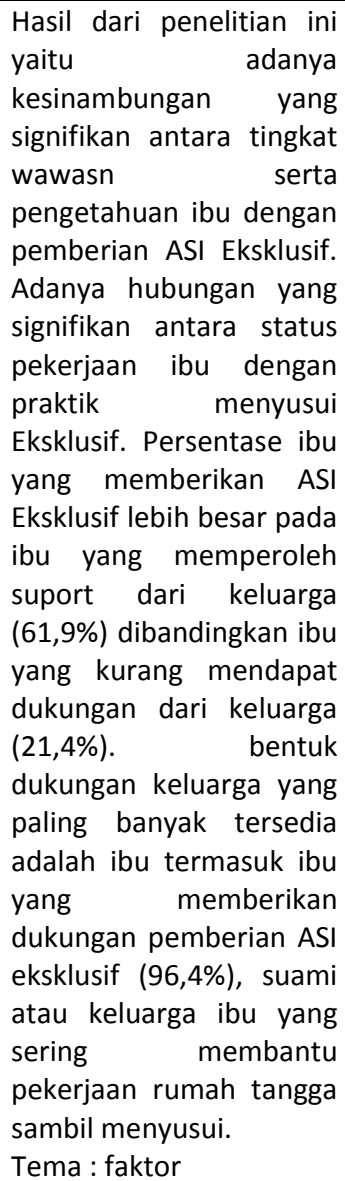 \\
\hline
\end{tabular}




\begin{tabular}{|c|c|c|c|c|c|c|}
\hline 4 & $\begin{array}{l}\text { (Prameswari and } \\
\text { Kurnia } \\
\text { 2018)/(Qualitative } \\
\text { Study of Exclusive } \\
\text { Breastfeeding } \\
\text { Succeded among } \\
\text { Working Mother) }\end{array}$ & $\begin{array}{l}\text { Indon } \\
\text { esia }\end{array}$ & $\begin{array}{l}\text { Tujuan dari } \\
\text { penelitian ini } \\
\text { yaitu untuk } \\
\text { mendeskripsika } \\
\text { n keberhasilan } \\
\text { pemberian ASI } \\
\text { eksklusif pada } \\
\text { ibu bekerja }\end{array}$ & $\begin{array}{l}\text { Studi } \\
\text { kualitati } \\
f\end{array}$ & 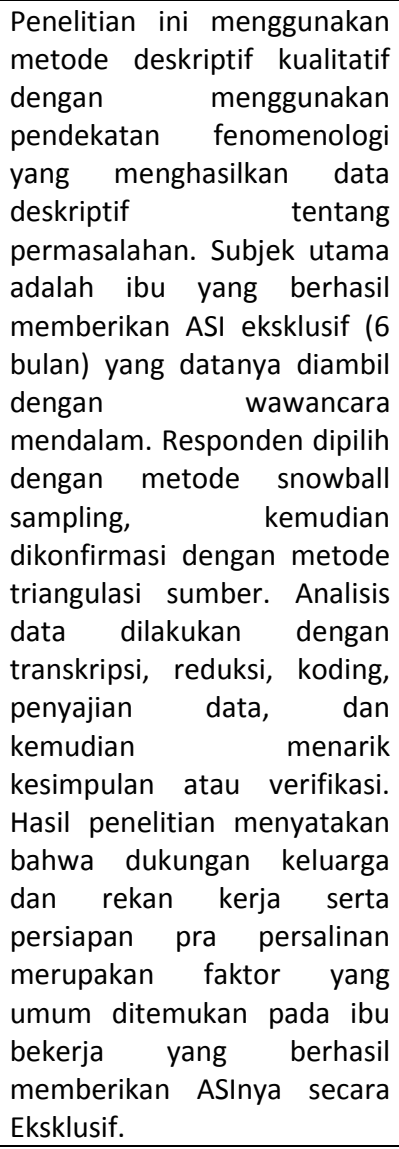 & 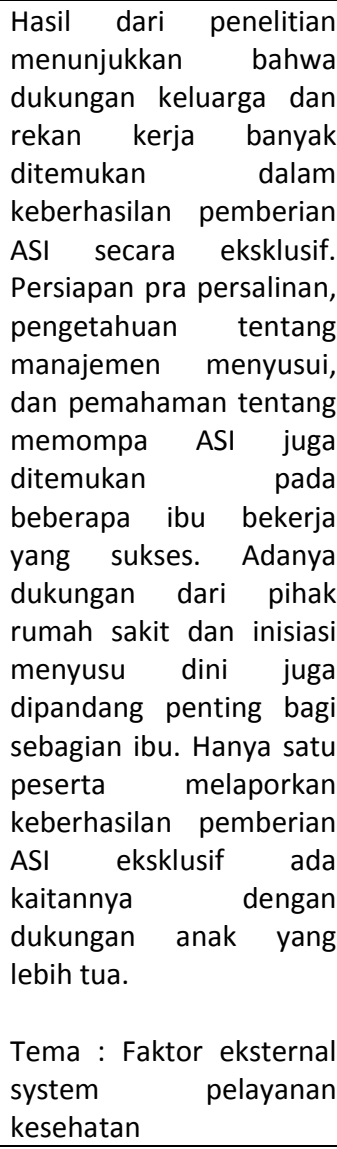 \\
\hline 5 & $\begin{array}{l}\text { (Ratnasari et al. } \\
\text { 2017)/(Family } \\
\text { support and } \\
\text { exclusive } \\
\text { breastfeeding } \\
\text { among Yogyakarta } \\
\text { mothers in } \\
\text { employment) }\end{array}$ & $\begin{array}{l}\text { Indon } \\
\text { esia }\end{array}$ & $\begin{array}{lr}\text { Tujuan dari } & \text { da } \\
\text { penelitia } & \text { ini } \\
\text { yaitu untuk } & \text { mengetahui } \\
\text { dukungan dari } \\
\text { keluarga dan } \\
\text { pemberian } \\
\begin{array}{ll}\text { Eksklusif pada } \\
\text { ibu-ibu } \\
\text { bekerja }\end{array}\end{array}$ & $\begin{array}{l}\text { Cross } \\
\text { sectiona } \\
\text { I }\end{array}$ & 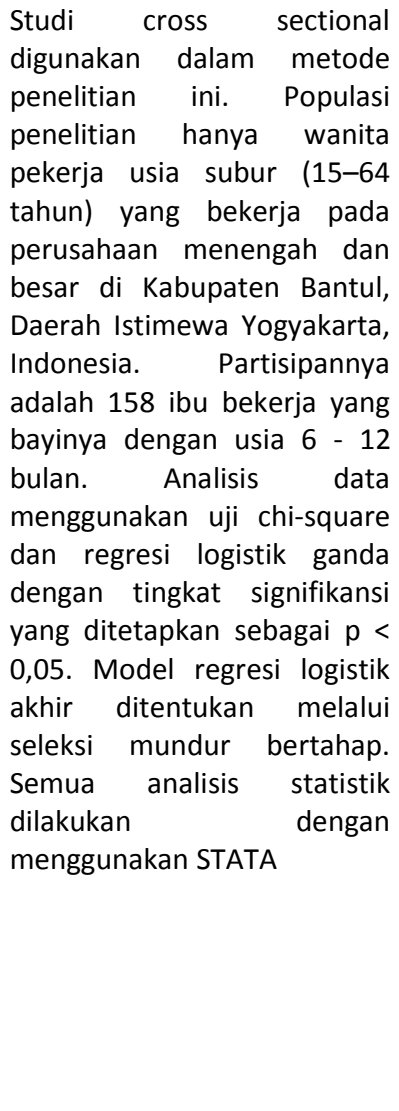 & 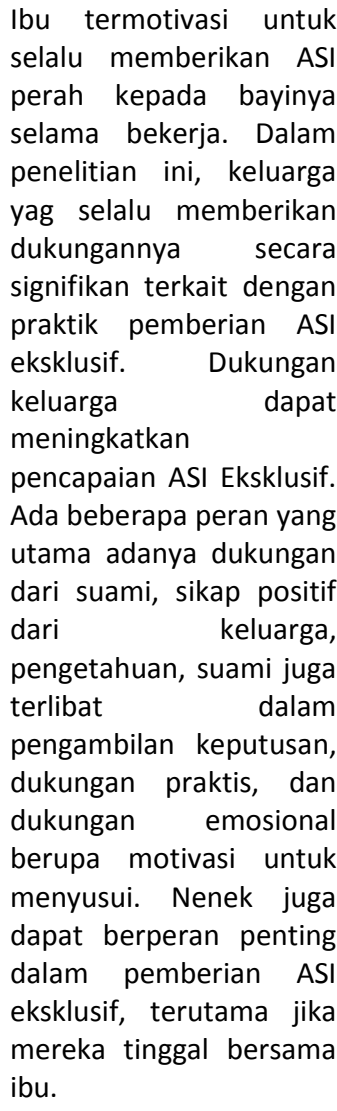 \\
\hline & & & & & & $\begin{array}{l}\text { Tema : bentuk - bentuk } \\
\text { dukungan }\end{array}$ \\
\hline 6 & $\begin{array}{l}\text { (Riaz and Condon } \\
\text { 2019)/(The }\end{array}$ & $\begin{array}{l}\text { Pakist } \\
\text { an }\end{array}$ & $\begin{array}{lr}\text { Tujuan } & \text { dari } \\
\text { penelitian } & \text { ini }\end{array}$ & $\begin{array}{l}\text { Studi } \\
\text { kualitati }\end{array}$ & $\begin{array}{l}\text { Penelitian ini disetujui oleh } \\
\text { komite etika Universitas }\end{array}$ & $\begin{array}{lll}\text { Pengasuhan anak telah } \\
\text { disediakan di dalam }\end{array}$ \\
\hline
\end{tabular}


experiences of

breastfeeding

mothers returning

to work as hospital

nurses in Pakistan:

A qualitative study)

yaitu Untuk
menggambarka
$\mathrm{n}$ sikap dan
pengalaman ibu
menyusui yang
kembali bekerja
penuh waktu
sebagai perawat
di rumah sakit
tersier di
Pakistan

Pakistan

Inggris dan izin untuk
merekrut peserta diperoleh
dari otoritas rumah sakit
terkait di rakistan
Pendekatan deskriptif
kualitatif diambil untuk
mengeksplorasi pengalaman
hidup perawat yang kembali
bekerja saat menyusui.
Wawancara kualitatif semi
terstruktur secara mendalam
dilakukan oleh fi penulis
pertama. Purposive sampling
digunakan untuk memilih
peserta dari rumah sakit
tersier di Pakistan. Tujuh
partisipan yang dijadikan
sampel secara purposif yang
sedang menyusui pada saat
kembali bekerja. Wawancara
direkam secara audio,
ditranskripsikan dan dianalisis
secara tematis.
secara tematis. rumah sakit selama dua

tahun terakhir, tetapi

hanya mencakup jam

shift siang. Para ibu

tertekan karena tidak diberi kesempatan untuk melanjutkan menyusui dan beberapa bayi digambarkan sangat gelisah dengan peralihan ke pemberian susu formula. Tidak hanya ibu yang ikut serta dalam pemberian makan bayi begitu seorang ibu sudah kembali bekerjanya. Keluarga juga dapat mengetahui cara bayi disusui. Peralihan dari pemberian ASI ke susu botol dapat mengakibatkan stres yang parah bagi keluarga, sementara bayi menyesuaikan diri dengan bentuk pemberian ASI yang berbeda.

Tema : dukungan praktikal, hambatan

7 (Valizadeh et al. Iran Tujuan dari Studi Studi kualitatif deskriptif dan 2017)/(Addressing barriers to health: Experiences of breastfeeding mothers after returning to work) $\begin{array}{lrll}\text { Tujuan } & \text { dari } & \text { Studi } & \text { Studi kualitatif deskriptif dan } \\ \text { peneliian } & \text { ini } & \text { kualitati } & \text { wawancara semi-terstruktur }\end{array}$ adalah untuk $f$ digunakan untuk memahami dan mengidentifikas i hambatan ibu menyusui setelah kembali bekerja
Pasangan dan atasan yang tidak mendukung berulang kali disebutkan, karena para ibu dilaporkan mengalami stres dan kelelahan karena menyusui dan bekerja untuk keuntungan finansial. Ibu yang bekerja mengalami rasa bersalah dan kecemasan akan perpisahan karena tidak berada di rumah dan harus menitipkan bayi mereka. Pasangan yang mendukung yang berbagi tanggung jawab keluarga dan persahabatan yang lebih baik dengan rekan kerja tampaknya menjadi sumber bantuan utama bagi ibu yang kelelahan dan stress.

Tema : faktor dukungan, hambatan 


\section{Langkah 5: Maping Data}

Hasil review ini di temukan beberapa tema yang dianggap paling relevan dengan focus review dipetakkan dalam tabel 4 .

Tabel 4. Tema

\begin{tabular}{|c|c|}
\hline TEMA & SUB TEMA \\
\hline $\begin{array}{llr}\text { 1. } & \text { Faktor } & \text { pengaruh } \\
\text { keberhasilan } & \text { dalam } \\
\text { pemberian ASI Eksklusif }\end{array}$ & $\begin{array}{l}\text { a. Faktor internal }[1][2][3][5] \\
\text { b. Faktor eksternal }[2][3][4][7]\end{array}$ \\
\hline 2. Bentuk dukungan & $\begin{array}{l}\text { a. Emosional [5] } \\
\text { b. Praktikal [3][5][6] } \\
\text { c. Informasional [5] }\end{array}$ \\
\hline $\begin{array}{l}\text { 3. Hambatan yang dialami } \\
\text { dalam pemberian ASI } \\
\text { Eksklusif }\end{array}$ & $\begin{array}{l}\text { a. Kurangnya pengetahuan [1] } \\
\text { b. Kurangnya dukungan di tempat } \\
\text { kerja [1] } \\
\text { c. Kurangnya dukungan keluarga } \\
\text { [2] }\end{array}$ \\
\hline
\end{tabular}

\section{Hasil dan Pembahasan}

Berdasarkan analisis dari ketujuh artikel, diperoleh tema-tema yang dapat dikelompokkan berdasarkan faktor pengaruh keberhasilan dalam pemberian ASI eksklusif, bentuk dukungan, hambatan yang dialami dalam praktik pemberian ASI esklusif.

\section{Faktor pengaruh terhadap keberhasilan dalam pemberian ASI eksklusif}

\section{a. Faktor internal}

Faktor internal terdiri dari faktor pengetahuan dan faktor psikologis. Faktor pengetahuan atau wawasan sangat mempengaruhi sikap serta perilaku. Ketidaktahuan ibu akan manfaat menyusui secara eksklusif merupakan hambatan utama. Pendidikan yang lebih efektif diperlukan untuk meningkatkan pengetahuan ibu tentang menyusui. Pendidikan merupakan faktor yang penting bagi ibu untuk memahami perilaku baik lebih baik (Sutter et al. 2018). Tingkat pendidikan ibu mempengaruhi pola menyusui semakin baik tingkat pendidikan seorang ibu semakin baik pula pola menyusui secara eksklusif (Asnea, Septiana, and Muttaqien 2021). Pentingnya pengetahuan selama kehamilan yang diperoleh ibu mengenai menyusui dan mempersiapkan kan peran barunya di saat kelahiran bayi (Nukpezah, Nuvor, and Ninnoni 2018).

Faktor terpenting dalam memahami perilaku manusia dalam memahami situasi adalah motivasi yang dapat mempengaruhi perilaku secara positif. Depresi pasca partum dapat menyebabkan resiko tidak berhasilnya menyusui (Figueiredo et al. 2013). Kurangnya produksi ASI juga dapat dipengaruhi oleh beberapa faktor diantaranya depresi atau stres pasca melahirkan. Peran tenaga kesehatan yang profesional harus memahami teori psikologis yang dapat membantu menjelaskan peran utama motivasi pada manusia, motivasi yang lebih tinggi dalam memulai dan melanjutkan menyusui. Ciri-ciri ibu yang termotivasi adalah seorang ibu yang merasa senang dan bahagia saat menyusui sedangkan ibu yang tidak termotivasi untuk menyusui bayinya ibu akan menyusui dengan jangka waktu yang sangat singkat (Sahin et al. 2019).

\section{b. Faktor eksternal}

Faktor eksternal terdiri dari faktor dukungan keluarga, status pekerjaan dan faktor petugas kesehataan atau system pelayanan kesehatan. Dukungan dari keluarga termasuk nenek menunjukkan hubungan yang signifikan dengan menyusui setidaknya selama 6 sampai 12 bulan (Muelbert and Giugliani 2018). Faktor dukungan suami sangat berpengaruh terhadap perilaku menyusui para ibu, dukungan suami dianggap memiliki sikap yang positif terhadap ibu yang cenderung aktif untuk menyusui (Rempel, Rempel, and Moore 2017). Ibu ibu yang tidak memperoleh dukungan dari suami lebih kecil kemungkinan untuk memberikan ASI secara eksklusif kepada anaknya dibandingkan dengan ibu yang memperoleh perhatian dan suaminya (Jama et al. 2020).

Salah satu aspek yang berdampak pada ibu bekerja dalam memberikan ASI eksklusif adalah status pekerjaan. Mayoritas bayi tidak disusui secara efektif oleh ibu yang bekerja. Ibu yang mempunyai kegiatan di luar rumah atau bekerja kecil kemungkinan untuk mempraktekkan ASI eksklusif dibandingkan dengan ibu yang tidak mempunyai kegiatan di luar rumah atau ibu yang tidak bekerja (Chekol et al. 2017).

Indikator terkuat dari inisiasi menyusu dini dan durasi efektif yang berkepanjangan memberikan nasehat dan edukasi oleh tenaga kesehatan merupakan syarat utama pemberian ASI serta realitas menyusui harus dipertimbangkan selama kehamilan (Alianmoghaddam, Phibbs, and Benn 2017). Pendidikan atau edukasi tentang cara pemberian makan pada bayi yang diberikan oleh tenaga kesehatan sangat berperan penting dalam memberikan pendidikan kesehatan atau health edukasi oleh tenaga kesehatan tentang pemberian ASI eksklusif penting diberikan selama kehamilan 
atau selama kehamilan kemudian diberikan lagi setelah pasca bersalin (Kristanti, Herawati, and Susilawati 2019).

\section{Bentuk dukungan}

\section{a. Dukungan emosional}

Dukungan emosional dianggap penting untuk wanita yang sedang menyusui. Dukungan penggunaan emosi positif dapat menigkatkan kemungkinan intervensi mempromosikan perilaku kesehatan menyusui eksklusif (Shepherd, Walbey, and Lovell 2017).

\section{b. Dukungan praktikal}

Dukungan praktikal yang diberikan pada ibu yaiutu dukungan yang diberikan oleh ibu atau mertua dalam membantu mengurus bayinya. Dukungan praktikal juga bisa diberikan oleh suami misalnya suami membanntu memandikan bayi, mengganti popok dan membantu melakukan pekerjaan rumah tangga (Rempel, Rempel, and Moore 2017).

\section{c. Dukungan informasional}

Dukungan infornasional diperoleh dari tenaga kesehatan misalnya bidan dan dokter. Beberapa masalah dapat ditangani dengan konseling dari tenaga kesehatan, ibu yang mengalami masalah laktasi lebih seringmelakuakn kinsultasi (Alianmoghaddam, Phibbs, and Benn 2017).

\section{Hambatan dalam pemberian ASI eksklusif}

Hambatan dalam pemberian ASI eksklusif pada ibu bekerja yaitu kurangnya dukungan dari tempat kerja, kurangnya istirahat, tempat laktasi, serta fasilitas penyimpanan susu perah di tempat kerja (Al-Katufi et al. 2020). Beban kerja dapat menyebabkan ibu mengalami kelelahan serta lamanya waktu bekerja menjadi penyebab gagalnya ibu dalam memberikan ASI eksklusif. Kurangnya pengetahuan tentang manfaat ASI serta kurangnya dukungan dari tenaga kesehatan juga menjadi hambatan ibu bekerja dalam memberikan ASI eksklusif (Fatimah and Eva 2019).

\section{Kesimpulan}

Salah satu cara untuk meningkatkan status kesehatan khususnya kesehatan pada bayi adalah dengan cara memberikan ASI eksklusif. Takaran ASI yang pas baik untuk tubuh bayi, serta kandungan serta gizi pada ASI sangat diperlukan untuk memenuhi gizi pada bayi. Dukungan keluarga pada ibu bekerja sangat baik justru hambatan yang dialami ibu terjadi pada tempat kerja. Tidak tersedianya tempat untuk ibu memberikan ASI atau tempat yang layak untuk ibu, menjadi salah satu hambatan ibu untuk memberikan ASI. Sehingga terjadi resiko yang menyebabkan Ibu tidak berhasil memberikan ASI eksklusif dan ibu beralih ke susu formula untuk memberikan nutrisi pada bayinya. Oleh sebab itu penyediaan tempat menyusui yang layak di tempat kerja sangat memengaruhi keberhasilan ibu bekerja dalam memberikan ASI Eksklusif.

\section{Daftar Pustaka}

Al-Katufi, Batool Ali et al. 2020. "Barriers in Continuing Exclusive Breastfeeding among Working Mothers in Primary Health Care in the Ministry of Health in Al-Ahsa Region, Saudi Arabia." Journal of family medicine and primary care 9(2): 957-72. https://pubmed.ncbi.nlm.nih.gov/32318452.

Alianmoghaddam, Narges, Suzanne Phibbs, and Cheryl Benn. 2017. "Resistance to Breastfeeding: A Foucauldian Analysis of Breastfeeding Support from Health Professionals." Women and Birth: 1-11. http://dx.doi.org/10.1016/j.wombi.2017.05.00 5.

Arksey, Hilary, and Lisa O'Malley. 2005. "Scoping Studies: Towards a Methodological Framework." International Journal of Social Research Methodology: Theory and Practice 8(1): 19-32.

Asnea, Anggit, Cesa Septiana, and Zaenal Muttaqien. 2021. "Factors Affecting Self-Efficiency in Breast Milk : A Rapid Review." 5(2): 160-76.

Chekol, Dawit Alemayehu, Gashaw Andargie Biks, Yalemzewod Assefa Gelaw, and Yayehirad Alemu Melsew. 2017. "Exclusive Breastfeeding and Mothers 'Employment Status in Gondar Town , Northwest Ethiopia: A Comparative Cross- Sectional Study." : 1-9.

Fatimah, Anggraeni, and Putriningrum Eva. 2019. “Hambatan Ibu Bekerja Dalam Memberikan ASI Eksklusif Pada Bayi Pada Ibu Menyusui Di WIlayah Kerja Puskesmas". Jurnal Kebidanan, XI(02): 147-59.

Februhartanty, Judhiastuty, Yulianti Wibowo, Umi Fahmida, and Airin Roshita. 2012. "Profiles of Eight Working Mothers Who Practiced Exclusive Breastfeeding in Depok, Indonesia." Breastfeeding Medicine 7(1): 54-58.

Figueiredo, Bárbara et al. 2013. "Breastfeeding and Postpartum Depression: 


State of the Art

Review G." Jornal de Pediatria 89(4): 332-38. http://dx.doi.org/10.1016/j.jped.2012.12.002

Hidayah Putri, Dian, Masrul Masrul, and Lisma Evareny. 2018. "The Relationship Between The Level of Maternal Knowledge, Maternal Employment Status and Family Support With Exclusive Breastfeeding in The Working Area of The Air Dingin Health Center of Padang City in 2018." Journal of Midwifery 3(2): 161.

Jama, Abdiasis et al. 2020. "Exclusive Breastfeeding for the First Six Months of Life and Its Associated Factors among Children Age 6-24 Months in Burao District, Somaliland." International Breastfeeding Journal 15(1): 1-8.

Kristanti, lin, Cucu Herawati, and Desi Susilawati. 2019. "Kontribusi Faktor Internal Dan Eksternal Determinan Perilaku Terhadap Pemberian ASI Ekslusif Pada Bayi Baru Lahir." Dimasejati: Jurnal Pengabdian Kepada Masyarakat 1(2): 245-57.

Muelbert, Mariana, and Elsa R J Giugliani. 2018. "Factors Associated with the Maintenance of Breastfeeding for 6,12 , and 24 Months in Adolescent Mothers." : 1-11.

Nukpezah, Ruth Nimota, Samuel Victor Nuvor, and Jerry Ninnoni. 2018. "Knowledge and Practice of Exclusive Breastfeeding among Mothers in the Tamale Metropolis of Ghana." Reproductive Health 15(1): 1-9.

Prameswari, Galuh Nita, and Arif Rahmat Kurnia. 2018. "Qualitative Study of Exclusive Breastfeeding Succeded among Working Mother." 12(Isphe): 185-90.

Ratnasari, Dewi et al. 2017. "Family Support and Exclusive Breastfeeding among Yogyakarta Mothers in Employment." Asia Pacific Journal of Clinical Nutrition 26(May): S31-35.

Rempel, Lynn A, John K Rempel, and Katrina C J Moore. 2017. "Original Article Relationships between Types of Father Breastfeeding Support and Breastfeeding Outcomes." : 1-14.

Riaz, Saadia, and Louise Condon. 2019. "The Experiences of Breastfeeding Mothers Returning to Work as Hospital Nurses in Pakistan: A Qualitative Study." Women and Birth 32(2): e252-58. https://doi.org/10.1016/j.wombi.2018.06.019.
Sahin, Berrak Mizrak, Nebahat Ozerdogan, Kazım Ozdamar, and Elif Gursoy. 2019. "Health Care for Women International Factors Affecting Breastfeeding Motivation in Primiparious Mothers: An Application of Breastfeeding Motivation Scale Based on Self- Determination Theory." Health Care for Women International 40(6): $637-52$. https://doi.org/10.1080/07399332.2018.15262 89.

Sartono, Agus, and Hanik Utaminingrum. 2012. "Hubungan Pengetahuan Ibu, Pendidikan Ibu Dan Dukungan Suami Dengan Praktek Pemberian Asi Eksklusif Di Kelurahan Muktiharjo Kidul Kecamatan Telogosari Kota Semarang." Gizi Universitas Muhhamadiyah Semarang 1(1): 1-9.

Shepherd, Lee, Cherokee Walbey, and Brian Lovell. 2017. "The Role of Social-Cognitive and Emotional Factors on Exclusive Breastfeeding Duration."

Sulistiyowati, and Siswantara. 2014. "PERILAKU IBU BEKERJA DALAM MEMBERIKAN ASI EKSKLUSIF DI KELURAHAN JAPANAN WILAYAH KERJA PUSKESMAS KEMLAGI- MOJOKERTO." : 89-100. http://library1.nida.ac.th/termpaper6/sd/2554 /19755.pdf

Sutter, Carolyn et al. 2018. "Sources of Information and Support for Breastfeeding : Alignment with Centers for Disease Control." 13(9).

Swastika, Chhetri, Rao Arathi, and Vasudeva Guddattu. 2018. "Factors Affecting Exclusive Breastfeeding (EBF) among Working Mothers in Udupi Taluk, Karnataka." Clinical Epidemiology and Global Health 6(4): 216-19. https://doi.org/10.1016/j.cegh.2018.06.008.

Valizadeh, Sousan et al. 2017. "Addressing Barriers to Health: Experiences of Breastfeeding Mothers after Returning to Work." Nursing and Health Sciences 19(1): 105-11.

Widiasih, Restuning, Raini Diah Susanti, C W M Sari, and ... 2020. "Menyusun Protokol Penelitian Dengan Pendekatan SETPRO: Scoping Review." Journal of Nursing ... 3(3): 171-80. http://journal.unpad.ac.id/jnc/article/view/288 31. 